\title{
Zieve's Syndrome - A Potential Surgical Pitfall?
}

\author{
Lt Col R Pilcher
}

BSc, FDS, LMSSA, RADC*

House Officer in Surgery

\section{Dr RG Underwood \\ $\mathrm{MB}, \mathrm{ChB}$}

Senior House Officer in Surgery

\section{Capt HR Smith \\ MRCP, RAMC}

Senior House Officer in Medicine

\author{
Cambridge Military Hospital, Aldershot, Hants. GU11 2AN.
}

SUMMARY: Zieve's syndrome consists of transient haemolytic anaemic, jaundice, hyperlipidaemia and alcoholinduced liver disease. It is rare with less than 75 cases reported in a Medicine literature search from 1966. It can present acutely with abdominal pain.

\section{Case Report}

A 39 year old male lorry driver presented with a twenty four hour history of central abdominal pain radiating to the back, fever and vomiting. He drank 20 units of alcohol per day. On examination he was febrile at $38^{\circ} \mathrm{C}$ and not jaundiced. He showed epigastric rebound tenderness. Fundal examination revealed lipaemia retinalis and venous samples were lipaemic.

Investigation showed: Haemoglobin $13.2 \mathrm{~g} / \mathrm{dl}(14-18)$, amylase $511 \mathrm{iu} /(16-108)$, cholesterol $33 \mathrm{mmol} / 1(3.7-5.4)$, triglycerides $129 \mathrm{mmol} / \mathrm{l}(0.5-2.0)$, ALT $110 \mathrm{iu} / \mathrm{l}(5-40)$, gamma GT 324iu/l(10-40), bilirubin $17 \mathrm{umol} / \mathrm{l}$, sodium $120 \mathrm{mmol} / \mathrm{l}$, potassium $3.2 \mathrm{mmol} / \mathrm{l}$, and urea $6.8 \mathrm{mmol} / 1$.

He was managed in a surgical unit with a presumptive diagnosis of pancreatitis. Upper gastrointestinal endoscopy and ultrasound of the abdomen were normal.

Following admission his abdominal pain and fever resolved over 5 days. All biochemical values returned to the normal range during this time. However simultaneously his haemoglobin fell to $8.8 \mathrm{~g} / \mathrm{dl}$, his bilirubin rose to $35 \mathrm{mmol} / \mathrm{l}$ and he became jaundiced. The blood film and reticulocyte count confirmed haemolysis. The diagnosis was revised to that of Zieve's syndrome.

His jaundice resolved over 3 days and after 4 weeks without alcohol the patient was clinically asymptomatic with a haemoglobin of $14 . \mathrm{lg} / \mathrm{dl}$.

\section{Discussion}

In 1958 Leslie Zieve described a syndrome in alcoholic patients of jaundice, hyperlipidaemia and haemolytic anaemic (1).

Abnormalities of red cell metabolism have been suggested as a cause of the haemolysis(2). This syndrome can occur in patients with or without pre-existent alcohw을 liver damage(3).

Melrose reported a series presenting with acufe abdominal pain and fever. Hyperlipidaemia was noted $\Phi^{\mathbb{D}}$ subside prior to the onset of haemolysis (4).

Zicve's syndrome can present as an acute abdomes. Abstention from alcohol leads to complete clinic remission and prevents recurrence.

\section{Acknowledgements}

We thank Lt Col CL Griffiths RAMC, Consultant Surgeon and Lt Col PJ Fabricius RAMC, Consultant Physician for permission to report on their patient.

\section{REFERENCES}

1. ZIEvE L. Jaundice, hyperlipaemia and haemolytic anaemia; A herefore unrecognised syndrome associated with alcoholic fatty liver and cirrhosis. Ann $\stackrel{\mathscr{N}}{\vec{F}}$ Intern Med, 1958; 48: 471.

2. Goebel KM. Red cell metabolism in transient haemolytic anaemia associated with Zieve'sô syndrome. Eur J Clin Invest, 1975; 5(1); 83-91.

3. Benraad MD, Penn HJ, Pieters, GFFM, Tan HS.으 Zieve's Syndrome. JR Coll Physicians. 1977; 12 (1): 42-52.

4. Melrose WD, Bell PA, Jude DM, Baikie MJ Alcohol-associated haemolysis in Zieve's syndrome: aN clinical and laboratory study of five cases. Clin Lab N Haematol, 1990; 12(2): 159-167. 